\title{
Comparing and contrasting the behaviour of Arctic and Antarctic sea ice over the 35 year period 1979-2013
}

\author{
Ian SIMMONDS
}

\author{
School of Earth Sciences, University of Melbourne, Parkville, Victoria, Australia \\ E-mail: simmonds@unimelb.edu.au
}

\begin{abstract}
We examine the evolution of sea-ice extent (SIE) over both polar regions for 35 years from November 1978 to December 2013, as well as for the global total ice (Arctic plus Antarctic). Our examination confirms the ongoing loss of Arctic sea ice, and we find significant $(p<0.001)$ negative trends in all months, seasons and in the annual mean. The greatest rate of decrease occurs in September, and corresponds to a loss of $3 \times 10^{6} \mathrm{~km}^{2}$ over 35 years. The Antarctic shows positive trends in all seasons and for the annual mean $(p<0.01)$, with summer attaining a reduced significance $(p<0.10)$. Based on our longer record (which includes the remarkable year 2013) the positive Antarctic ice trends can no longer be considered 'small', and the positive trend in the annual mean of $(15.29 \pm 3.85) \times 10^{3} \mathrm{~km}^{2} \mathrm{a}^{-1}$ is almost one-third of the magnitude of the Arctic annual mean decrease. The global annual mean SIE series exhibits a trend of $(-35.29 \pm 5.75) \times 10^{3} \mathrm{~km}^{2} \mathrm{a}^{-1}(p<0.01)$. Finally we offer some thoughts as to why the SIE trends in the Coupled Model Intercomparison Phase 5 (CMIP5) simulations differ from the observed Antarctic increases.
\end{abstract}

KEYWORDS: Antarctic glaciology, Arctic glaciology, atmosphere/ice/ocean interactions, climate change, ice and climate

\section{INTRODUCTION}

The polar regions of the Earth play a key role in determining the nature of global climate. While the tropics and subtropics are regions of net radiative input, there is net radiative loss over the high latitudes (i.e. outgoing longwave radiation exceeds absorbed shortwave radiation). It is the 'task' of the atmospheric (and to a lesser extent the oceanic) circulation to redress these imbalances (and to produce a quasi-steady climate) by transporting energy (primarily in the form of sensible heat, latent heat and potential energy) from the tropics to the polar regions. Seen from this perspective not only is the nature of the tropical processes and conditions important for the workings of the general circulation, but so too are the dispositions of the polar regions. For this and many other reasons, a comprehensive understanding of global dynamics and thermodynamics must involve consideration of the polar regions.

There is strong evidence to indicate that changes in the concentrations of 'greenhouse' gases in the atmosphere are leading to many changes in global climate. These changes are more marked in specific areas. For example, in recent decades the Arctic region surface temperature has increased by about twice the global average, the so-called 'Arctic amplification' (Screen and Simmonds, 2010). Many of the physical processes that dominate climate in the polar regions are strongly influenced by sea ice. For example, sea ice effectively forms a barrier between the ocean and the atmosphere and hence dramatically changes the nature of air-sea interaction. In addition, the shortwave albedo of ice is $0.8-0.9$ while that of polar water is $\sim 0.1$ and hence the radiative components of the surface energy budget greatly depend on whether ice is present or not. Recent research by, for example, Screen and Simmonds (2012) and Pistone and others (2014) has quantified the large role that this feedback plays in the radiative forcing. Hence, sea ice presents an additional complicating factor when considering the climate of polar regions.
It is the behaviour of sea ice in the two polar regions that is of interest in this paper. Only a few past studies have addressed this 'bi-polar' aspect, including Turner and Overland (2009). In recent decades the Arctic sea-ice extent (SIE; defined as the area of ice that has a concentration in excess of $15 \%$ ) has shown dramatic decreases, particularly in September. These reductions have been the subject of much research (e.g. Walsh and Chapman, 2001; Cavalieri and Parkinson, 2012; Comiso, 2012; Stroeve and others, 2012a; Walsh, 2013). On a longer timescale there are numerous studies that point to present Arctic SIE changes as being anomalous compared to events over the past few thousand years (e.g. Polyak and others, 2010; Kinnard and others, 2011; Spielhagen and others, 2011). By contrast, it has been reported that the Antarctic SIE has exhibited 'small' increases over this period (Cavalieri and Parkinson, 2008; Parkinson and Cavalieri, 2012). This net increase in sea-ice extent comes about from the sum of positive and negative regional trends around the Antarctic periphery.

The morphology of the two polar regions is very different, so a priori it may not come as a surprise that their sea-ice trends differ. Most of the sea ice in the Northern Hemisphere $(\mathrm{NH})$ is found in the Arctic Ocean. This ocean is centred approximately over the North Pole and is surrounded by continents. There is therefore limited oceanic access from the Arctic Ocean to the mid-latitudes, this being mainly through the relatively 'narrow' Bering and Fram Straits. Hence the sea-ice zone is far to the north of the mid-latitude storm tracks and not particularly subject to their influence. By contrast, the broad region about the South Pole is occupied by the Antarctic ice sheet whose elevation in places exceeds $4 \mathrm{~km}$. The continent slopes down to meet the Southern Ocean at $\sim 70^{\circ} \mathrm{S}$ (depending on the longitude); the sea-ice zone then starts and has the whole Southern Ocean in front of it. The sea-ice zone extends, in some sectors and seasons, to $\sim 55^{\circ} \mathrm{S}$, well into the westerlies (Simmonds and others, 2005). Another aspect of difference between the two 
sea-ice regions is that the southern region is host to strong baroclinicity and frequent intense storms (Simmonds and others, 2003) which affect, and are affected by, the distribution of sea ice. In addition, the steep slopes and strong inversions over the Antarctic continent give rise to intense katabatic flows which have no counterpart in the Arctic. These flows play an important role in the generation and maintenance of coastal polynyas. The surface waters in the southern ice zone are $\sim 3-4$ psu (practical salinity units) more saline than those in the Arctic basin (Zweng and others, 2013), while the Antarctic ice zone receives approximately three times as much precipitation (Adler and others 2003). As a final point we comment that the modes of atmospheric variability that influence the Southern Ocean (e.g. Simmonds and Jacka, 1995; Simmonds, 2003), and the scale and processes (including water mass formation) in the Southern Ocean are much more complex than those in the Arctic Ocean.

Sea ice is known to vary over a wide range of timescales, and hence the nature of diagnosed trends may be specific to the particular period chosen (Watkins and Simmonds, 2000). In this paper, we analyse the satellite sea-ice record in the two hemispheres up to the present (1979-2013). This longer record grants us greater statistical confidence in the nature of variability and trends than has been possible heretofore, particularly in light of the extraordinary behaviour of Southern Hemisphere (SH) sea ice in 2013, namely record or near-record extents for all months of the year. We also perform analyses on the temporal behaviour of the global total (i.e. Arctic plus Antarctic) sea-ice coverage. We finally offer some comments on the comparison of Antarctic sea-ice trends in observations and the World Climate Research Program's Coupled Model Intercomparison Project Phase 5 (CMIP5) models.

\section{DATA AND METHODS}

The Arctic and Antarctic sea-ice data we use here are derived from a succession of satellite passive-microwave measurements which have provided an almost seamless global time series of coverage. Monthly mean data of SIE were downloaded from the National Snow and Ice Data Center (NSIDC, Boulder, CO, USA) for 35 years from November 1978 to December 2013.

These extents are derived from satellite passive-microwave data from the Scanning Multichannel Microwave Radiometer (SMMR) on the NASA Nimbus 7 satellite, the Special Sensor Microwave/Imager (SSMI) on the F8, F11 and F13 satellites of the US Defense Meteorological Satellite Program (DMSP), and the Special Sensor Microwave/Imager Sounder (SSMIS) on the DMSP F17 satellite. A large number of studies have established the accuracy of these datasets and, in particular, the techniques that have been used to account for the changes in the sensors used (and their resolution and sensitivity) over time (e.g. Cavalieri and others, 1999, 2012; Parkinson and Cavalieri, 2012; and references therein). A broad overview of these data is presented by Fetterer and others (2002). The months December 1987 and January 1988 were flagged in the NSIDC archive as having insufficient satellite data available to process the extent values. Guided by the fact that sea-ice anomalies have significant multi-month persistence (e.g. Blanchard-Wrigglesworth and others, 2011) we have here filled in these gaps by linear interpolation between the

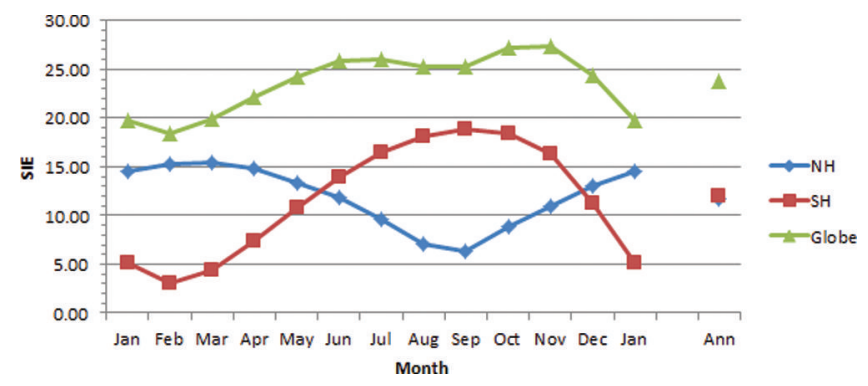

Fig. 1. Mean annual cycle of SIE (November 1978-December 2013) for the NH (blue diamonds), $\mathrm{SH}$ (red squares) and the globe (green triangles). Also shown are the annual means of the three series. Note that the symbol for the annual mean for the $\mathrm{NH}$ $\left(11.77 \times 10^{6} \mathrm{~km}^{2}\right)$ lies beneath that for the $\mathrm{SH}\left(12.02 \times 10^{6} \mathrm{~km}^{2}\right)$.

anomalies of November 1987 and February 1988. This approach to filling data gaps is clearly physically more realistic than others that have been used, such as filling gaps with linear interpolation between the same month in the previous year and following year (e.g. Eisenman and others, 2011) or with the climatological mean (e.g. Simpkins and others, 2013). The trends calculated below are determined from the straight line of best fit (using the standard leastsquares approach), complemented by the calculation of the standard error. In some cases we fit a quadratic through the data, again following the standard least-squares method.

Our analysis includes the diagnosis of atmospheric structures which are associated with sea-ice behaviour. For this we have used the European Centre for Medium-Range Weather Forecasts' ERA-Interim global reanalysis (Dee and others, 2011). The choice of this reanalysis set was guided by its superior overall performance in the polar regions and, in particular, in high southern latitudes (e.g. Bracegirdle and Marshall, 2012), in comparison to other reanalyses. We use here the period 1979-2013.

The dominant mode of $\mathrm{SH}$ atmospheric variability is the Southern Annular Mode (SAM). The SAM is characterized by a meridional seiche of mass between about 40 and $65^{\circ} \mathrm{S}$, and is intimately tied up with many circulation features of the $\mathrm{SH}$ and, in particular, the preferred paths of synopticscale weather systems (e.g. Rashid and Simmonds, 2005). As the index for this we have used the data provided by Marshall (2003) (and updates) (http://www.nerc-bas.ac.uk/ icd/gjma/sam.html), again using the period 1979-2013. In all the atmospheric analysis presented here, we follow the convention (e.g. Marshall, 2003) that the year attributed to December-February (DJF) is the year of the December.

\section{RESULTS}

\subsection{Sea ice}

We show in Figure 1 the mean annual cycle of $\mathrm{NH}$ and $\mathrm{SH}$ SIE compiled from the 35 year record. The Arctic curve reveals a maximum of $15.49 \times 10^{6} \mathrm{~km}^{2}$ in March and a September minimum of $6.40 \times 10^{6} \mathrm{~km}^{2}$. The analogous values for the Antarctic region are $18.83 \times 10^{6} \mathrm{~km}^{2}$ (September) and $3.06 \times 10^{6} \mathrm{~km}^{2}$ (February). Also exhibited in the figure is the sum of the two time series, i.e. the annual cycle of the global total of sea ice. This shows a broad maximum during the austral winter and spring, with the absolute maximum occurring in November $\left(27.30 \times 10^{6} \mathrm{~km}^{2}\right)$. The graphs show that this maximum occurs after the austral 

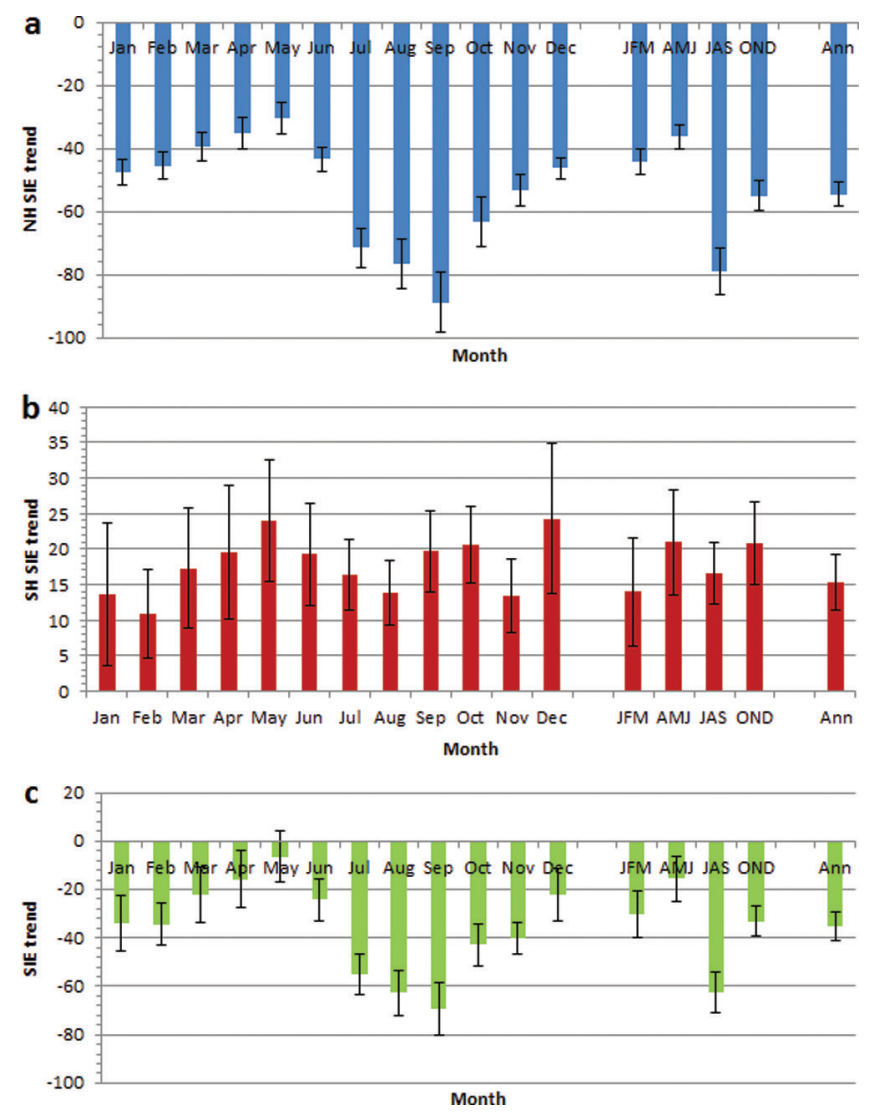

Fig. 2. Monthly trends in SIE (November 1978-December 2013) for (a) the $\mathrm{NH}$, (b) the $\mathrm{SH}$ and (c) the globe. The whiskers indicate the standard errors. Also shown are the trends in the seasonal and annual time series.

maximum because at that time the rate of decrease of southern ice is more than compensated by the regrowth of northern ice. The annual means of the SIE are 11.77, 12.02 and $23.79 \times 10^{6} \mathrm{~km}^{2}$ for the $\mathrm{NH}, \mathrm{SH}$ and globe, respectively. It is of interest to note that with the recent opposing SIE trends in the two hemispheres the annual mean in the south now exceeds that in the north.

The calendar-month trends of boreal SIE are determined from the least-squares line of best fit, and these are shown in Figure 2a. It is preferable to display these as absolute trends as we have done here rather than percentage (or 'relative') trends as are often shown, as the latter approach can distort the magnitude for months with low climatological sea-ice coverage. Another reason for considering absolute trends is that these have direct physical implications for changes in air-sea fluxes, air-ocean-sea-ice interactions, input of mechanical energy into the ocean, etc., associations that do not hold for relative changes. In addition, as pointed out by Wohlleben and others (2013), the magnitude of the relative trend depends on the reference value or period used, which can cause confusion when the results from different studies are being compared. We are very much in accord with their view that 'scientific studies involving the intercomparison of trends should restrict themselves to the use of absolute trends to avoid ambiguity'.

The trends are negative in all months, with the smallest magnitude in May $\left(-30.45 \times 10^{3} \mathrm{~km}^{2} \mathrm{a}^{-1}\right)$ and largest in September $\left(-88.96 \times 10^{3} \mathrm{~km}^{2} \mathrm{a}^{-1}\right)$. The whiskers on the bars in Figure $2 \mathrm{a}$ indicate the standard error, and these are all much smaller than the trends. Table 1 presents the numerical values for these parameters, as well as indicating the statistical significance. The table indicates that the 12 monthly trends are significantly different from zero at the $99 \%$ confidence level (and indeed at $p<0.001$ ). The second group of bars in Figure $2 \mathrm{a}$ indicates the trends in seasonal means (and we have here followed the 'sea-ice' season convention of Cavalieri and Parkinson (2012) of defining boreal winter as January-March (JFM), etc.). All these seasonal trends are also highly significant $(p<0.01)$, with the greatest trend in summer (JAS). Finally, the last bar indicates a similarly robust downward trend in the annual means.

An analogous display for the $\mathrm{SH}$ is presented in Figure $2 \mathrm{~b}$ (and Table 1). All monthly trends are seen to be positive, with the largest being found in May and December (the latter exhibiting $24.27 \times 10^{3} \mathrm{~km}^{2} \mathrm{a}^{-1}$ ). The error bars suggest less confidence in the trends compared to the $\mathrm{NH}$ case. All trends, except for January, are significant at the $90 \%$ level, ten are significant at $95 \%$ and six at $99 \%$, with these last tending to occur in the second half of the year. The seasonal and annual $\mathrm{SH}$ trends all reach the $99 \%$ level, with the exception of AMJ $(p>0.1)$.

The monthly trends of the global SIE are all positive (Fig. 2c; Table 1), and eight of these are significantly so $(p<0.01)$. The trend is not significant in April and May, and only marginally so $(p<0.1)$ in March and December. Overall, however, there is a significant $(p<0.01)$ trend in the global annual total of $-35.29 \times 10^{3} \mathrm{~km}^{2} \mathrm{a}^{-1}$. Three of the

Table 1. Monthly, seasonal, and annual trends in SIE (November 1978-December 2013) for the NH, SH and the globe. The units are $10^{3} \mathrm{~km}^{2} \mathrm{a}^{-1}$. Also presented are the standard errors (SE). The statistical significance of the trends is indicated by the typeface: bold ( $\left.p=0.01\right)$, bold italic $(p=0.05)$ or italic $(p=0.10)$

\begin{tabular}{|c|c|c|c|c|c|c|c|c|c|c|c|c|c|c|c|c|c|}
\hline & Jan & Feb & Mar & Apr & May & Jun & Jul & Aug & Sep & Oct & Nov & Dec & JFM & AMJ & JAS & OND & Ann \\
\hline \multicolumn{18}{|l|}{$\mathrm{NH}$} \\
\hline Trend & -47.55 & -45.48 & -39.54 & -35.19 & -30.45 & -43.41 & -71.60 & -76.54 & -88.96 & -63.35 & -53.50 & -46.36 & -44.19 & -36.35 & -79.03 & -55.03 & -54.58 \\
\hline SE & 3.97 & 4.37 & 4.59 & 4.96 & 5.17 & 3.80 & 6.38 & 7.78 & 9.50 & 7.77 & 5.01 & 3.43 & 3.97 & 3.72 & 7.39 & 4.86 & 3.70 \\
\hline \multicolumn{18}{|l|}{$\mathrm{SH}$} \\
\hline Trend & 13.61 & 10.96 & 17.23 & 19.53 & 24.03 & 19.23 & 16.38 & 13.89 & 19.65 & 20.56 & 13.34 & 24.27 & 13.94 & 20.93 & 16.64 & 20.73 & 15.29 \\
\hline SE & 10.06 & 6.24 & 8.45 & 9.49 & 8.52 & 7.23 & 4.95 & 4.56 & 5.71 & 5.42 & 5.19 & 10.59 & 7.56 & 7.45 & 4.30 & 5.83 & 3.85 \\
\hline \multicolumn{18}{|c|}{ 然 } \\
\hline Trend & -33.93 & -34.52 & -22.31 & -15.67 & -6.42 & -24.19 & -55.22 & -62.65 & -69.31 & -42.80 & -40.17 & -22.09 & -30.25 & -15.43 & -62.39 & -33.10 & -35.29 \\
\hline SE & 11.39 & 8.63 & 11.41 & 11.71 & 10.75 & 8.56 & 8.54 & 9.28 & 10.75 & 8.57 & 6.63 & 10.98 & 9.80 & 9.28 & 8.54 & 6.28 & 5.75 \\
\hline
\end{tabular}



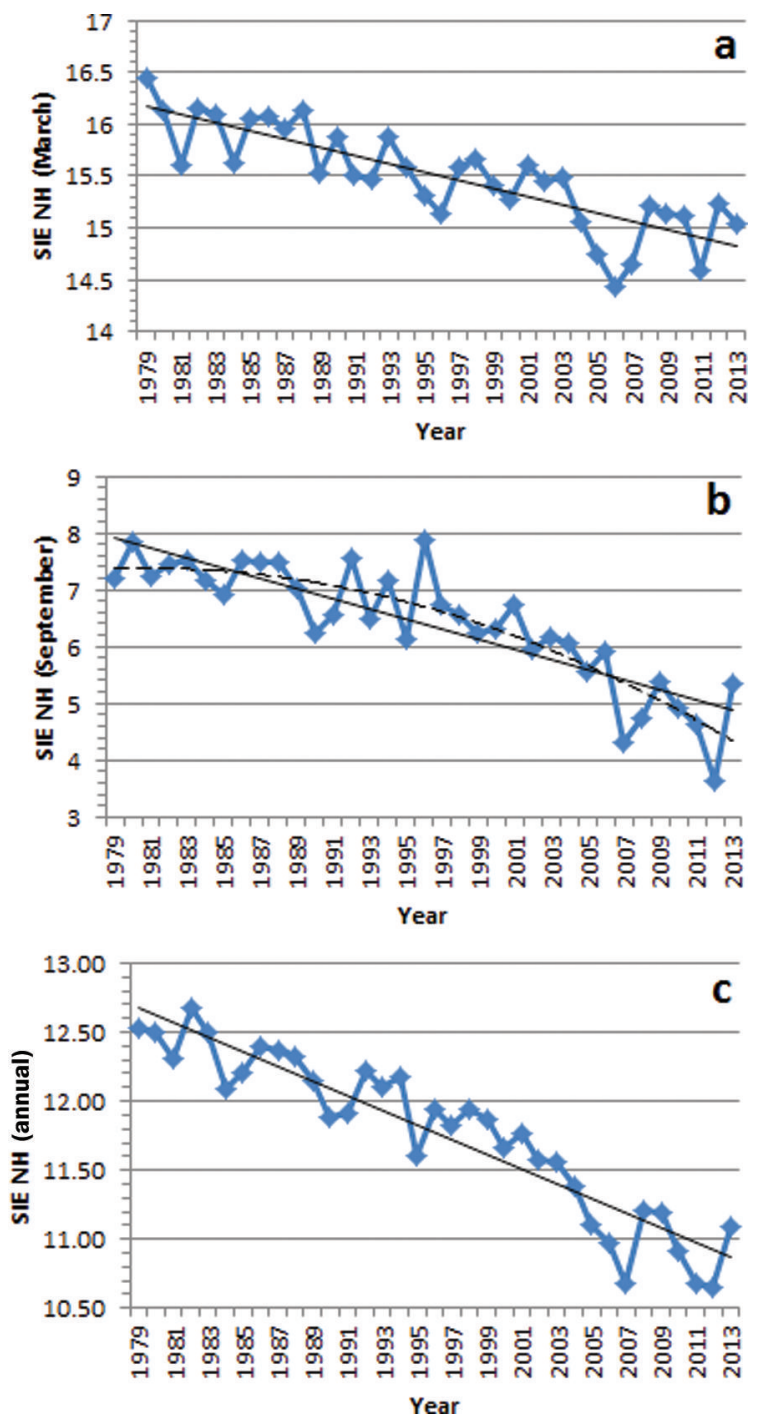

Fig. 3. Time series of NH SIE in (a) March, (b) September and (c) for the annual mean. Each graph displays the straight line of best fit to the data. In (b) the quadratic line of best fit is also shown (dashed line). The $r^{2}$ of the linear fits are (a) 0.69 , (b) 0.73 and (c) 0.74 . The $r^{2}$ of the September quadratic fit is 0.79 .

seasons also show this level of significance, while the trend identified in AMJ cannot be said to be above the noise level.

Complementing these, we show in Figure 3a the time series of Arctic SIE for the calendar month in which it exhibits its climatological maximum, i.e. March. As would be expected from the magnitude of the standard error presented in Table 1, there is considerable variability about the trend line, but we have seen the slope is significantly negative. The lowest value was recorded in 2006, with 2011 almost reaching that level. Figure $3 \mathrm{~b}$ presents similar information for September, the month of least $\mathrm{NH}$ ice cover. The record low of $3.63 \times 10^{3} \mathrm{~km}^{2}$ was reached in 2012 and smashed the already dramatic record set in 2007 (Simmonds and Rudeva, 2012). The highest September value was reached in 1996, and a number of authors have commented that the decay of the autumn sea ice appeared to accelerate in the 1990s (e.g. Maslanik and others, 2007; Simmonds and others, 2008; Simmonds and Keay, 2009). To highlight this, we show in the figure the quadratic curve of best fit to the data, and it serves to quantify the accelerating negative trend. Figure $3 \mathrm{c}$ plots the evolution of the annual mean
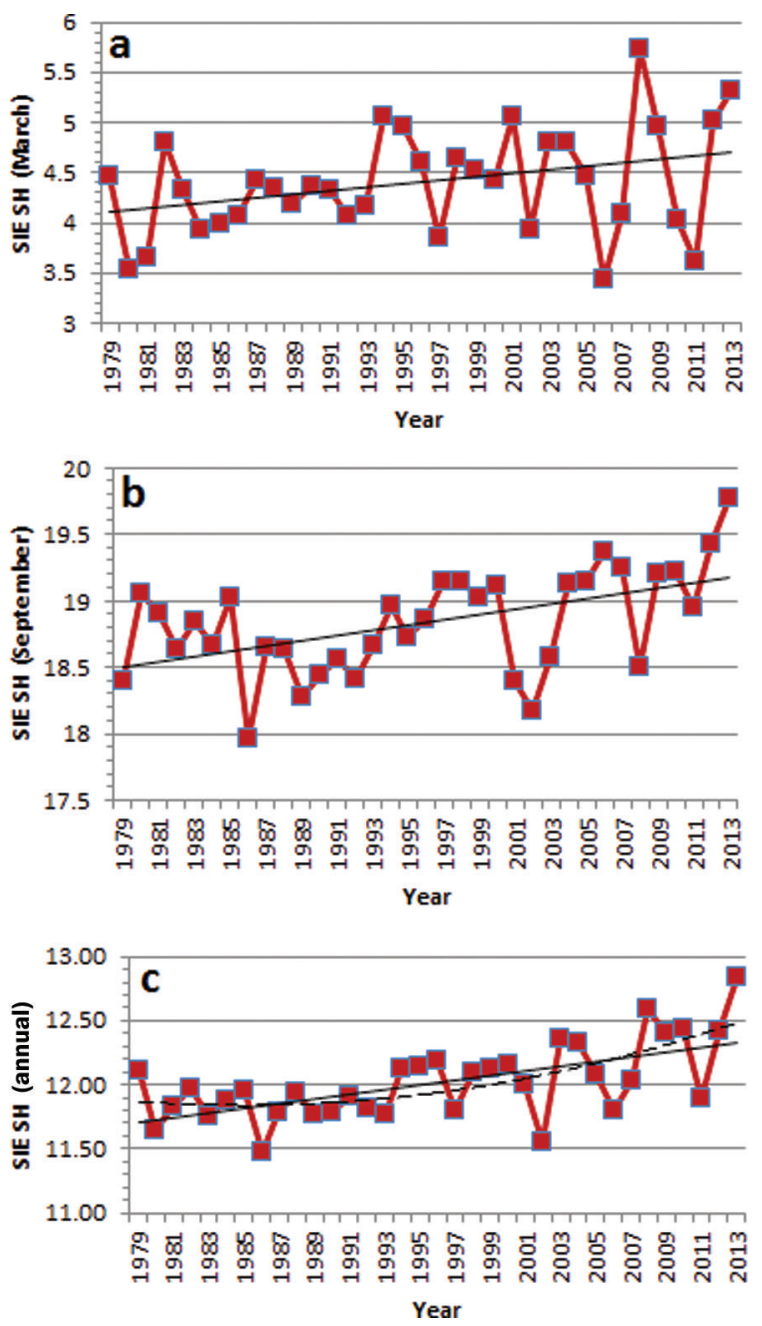

Fig. 4. Time series of SH SIE in (a) March, (b) September and (c) for the annual mean. Each graph displays the straight line of best fit to the data. In (c) the quadratic line of best fit is also shown (dashed line). The $r^{2}$ of the linear fits are (a) 0.11 , (b) 0.26 and (c) 0.39 . The $r^{2}$ of the annual quadratic fit is 0.43 .

Arctic SIE and its very strong downward trend. The year 2012 posted the lowest annual mean $\left(10.65 \times 10^{6} \mathrm{~km}^{2}\right)$, just beating the $10.68 \times 10^{6} \mathrm{~km}^{2}$ set in both 2007 and 2011 .

Figure 4 offers a comparable display for Antarctic SIE. The statistics indicate that the March trend of $17.23 \times 10^{3} \mathrm{~km}^{2} \mathrm{a}^{-1}$ only just achieves significance at the $95 \%$ level. There is considerable sub-decadal variability in this and other time series, a point made by Simpkins and others (2013). As an example of this timescale of variability, we point out that the minimum and maximum over the 35 year record are separated by only 2 years (2006 and 2008). The significance level of the increase in September is much greater, and we note that the record set in 2012 was broken in 2013 by quite a large margin. In fact the September 2013 SIE of $19.77 \times 10^{6} \mathrm{~km}^{2}$ was the greatest of any month of our 422 month sample. The time series of the annual mean $\mathrm{SH}$ SIE is shown in Figure 4c and, in particular, emphasizes how unusual 2013 was. The previous highest annual mean was $12.60 \times 10^{6} \mathrm{~km}^{2}$ (in 2008), but now that record stands at $12.85 \times 10^{6} \mathrm{~km}^{2}$. Consistent with this behaviour we remark that the last five months of 2013 recorded the greatest SIE (for their respective calendar months) over our analysis period. In the other seven months of the year the ice extent was at least the fifth most extensive, with the sole exception of January 

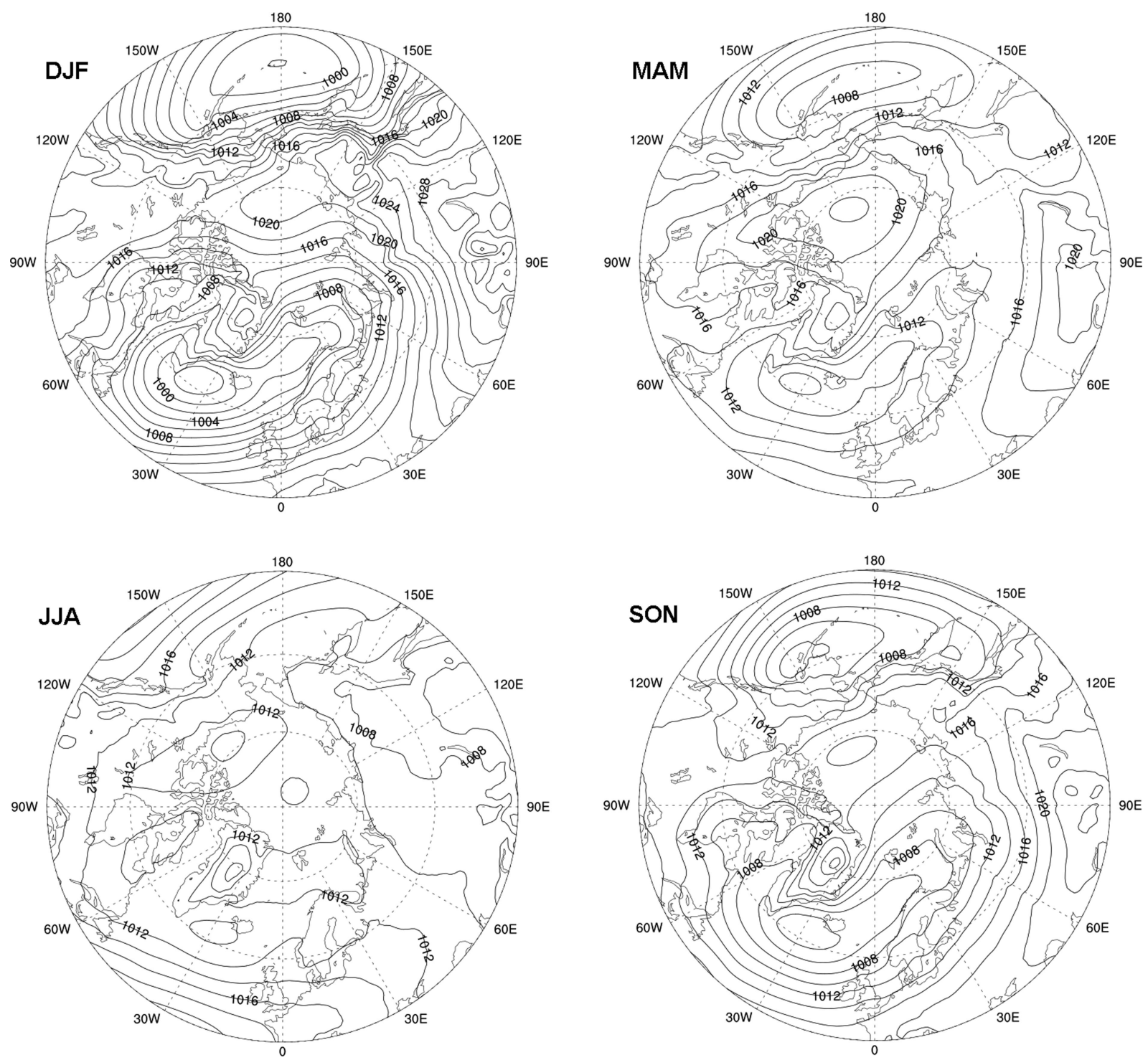

Fig. 5. High northern latitude climatological distributions of SLP for the four seasons for the period 1979-2013 in the ERA-Interim reanalysis. The contour interval is $2 \mathrm{hPa}$.

(eighth most extensive). We commented above that the September Arctic decrease appeared to have accelerated about the mid- to late 1990s. The structure of Figure 4c also suggests a change in trend about this time. The inclusion here also of the quadratic line of best fit reinforces this perspective of some quite rapid changes at the end of the data period, and we note that five of the heaviest $\mathrm{SH}$ sea-ice years have fallen in the last six years.

\subsection{Atmospheric circulation}

The distribution of sea ice is influenced by a number of factors, an important one of which is the atmospheric circulation (Wassermann and others, 2006; Holland and Kwok, 2012), and we wish here to explore the extent to which the trends documented above can be associated with circulation changes. In undertaking this, it is important to appreciate the background spatial structure of the mean sealevel pressure (SLP) distributions.

We present the mean SLP distributions in the four seasons (the seasons being defined here in the 'meteorological' sense of December-February (DJF), etc.). These are obtained from the ERA-Interim reanalysis for the period 1979-2013. Figure 5 shows that in DJF the high latitudes are strongly influenced by the Aleutian and Icelandic lows and the Siberian high, the last exerting a direct influence into the Arctic basin. In MAM these features become weaker and the centre of the Arctic high has moved from the Siberian coast to the central Arctic at $\sim 150^{\circ} \mathrm{W}$. In JJA (boreal summer) the mean circulation is considerably weaker, with the polar high moving into the Beaufort Sea in this modern climatology and lower pressures dominating much of the Arctic basin. Finally, in SON the Arctic high has moved slightly to the west, and the mean sub-arctic pattern starts to resemble that in winter.

The 1979-2013 Antarctic SLP climatology (Fig. 6) shows the strong mid-latitude westerlies and the circumpolar trough (CPT) all year round. In DJF there are distinct lows within the CPT, located in the Amundsen/Bellingshausen Seas, off Dronning Maud Land, and a weaker system to the northwest of Wilkes Land. The SLP exhibits a strong semiannual oscillation (SAO) (Simmonds and Jones, 1998; Simmonds and King, 2004) which drives the deepening of the trough seen in MAM and tends to make the SLP more zonally symmetric. The trough undergoes weakening into the austral winter (JJA), and there is a significant low centred just to the east of the Ross Sea. In SON, as dictated by the 

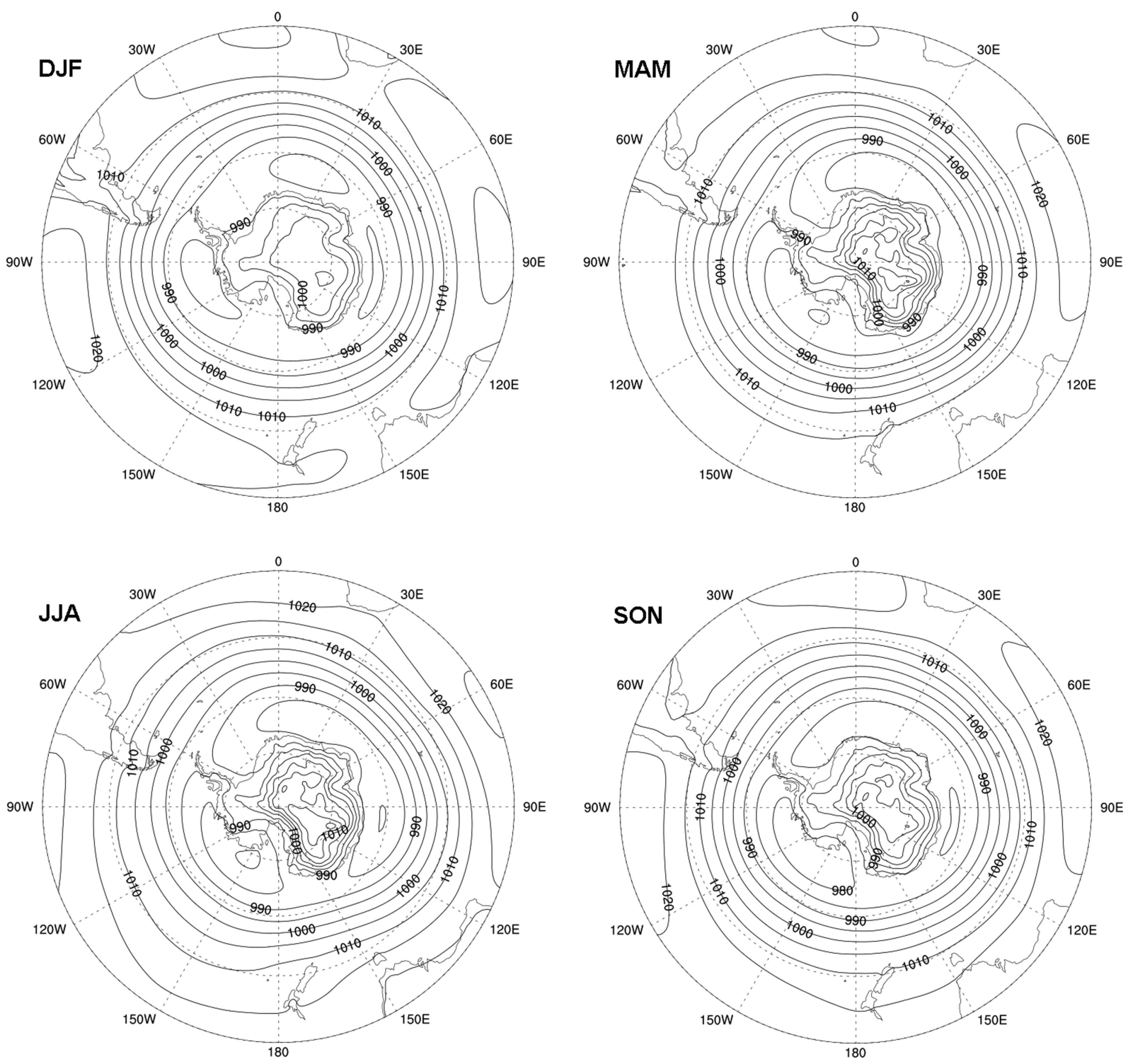

Fig. 6. High southern latitude climatological distributions of SLP for the four seasons for the period 1979-2013 in the ERA-Interim reanalysis. The contour interval is $5 \mathrm{hPa}$.

dynamic and thermodynamic processes that drive the SAO, the CPT assumes its greatest annual depth (and associated increase in the westerlies) and the Ross Sea low starts its extension eastwards. SON is also the season in which the CPT assumes its more southerly position. In the SH the CPT and the sea-ice edge have different seasonal cycles, and their relative latitudinal positions have important implications for the meridional flux of ice. As discussed by Enomoto and Ohmura (1990) and Simmonds and others (2005), in autumn the sea-ice edge lies mostly near, or south of, the trough, while in spring the edge is almost everywhere north of the CPT. The relative placement of the ice edge determines the meridional direction of the Ekman component of the sea-ice transport. In autumn the Ekman transport is to the south in most sectors and this discourages expansion of the ice edge, while in spring this transport is to the north, and the ice mass is, in turn, replenished by ice formed at higher latitudes.

The northern high-latitude SLP trends are shown in Figure 7 for the four seasons. The regions of interest here are of high interannual variability, and hence over many regions the trend is not significant (95\%), even though it may be quite large. Among the significant changes of note are the SLP reduction over western Russia in MAM which, by strengthening the westward surface wind over the Barents Sea, has the potential to increase the southward ice flux through Fram Strait in the summer. Also of note is the dipole pattern in the Arctic region in JJA which has been implicated in the increase in flux out of the Arctic and SIE reductions in SON (Maslanik and others, 2007; Ogi and others, 2010; Overland and Wang, 2010; Screen and others, 2011; Ogi and Wallace, 2012; Vihma and others, 2012; Ogi and Rigor, 2013).

In contrast to the north, the high southern latitudes SLPS have exhibited strong and significant changes over the 35 years considered here (Fig. 8). The summer season (DJF) shows a very strong annular structure to the trends, and the SAM is known to impact on sea-ice distribution (e.g. Maksym and others, 2012; Pezza and others, 2012). The time series of the DJF SAM index in Figure 9a shows a significant positive trend $\left(5.84 \pm 2.61(100 \mathrm{a})^{-1}, p<0.05\right)$. When considered against the structure of the background climatology (Fig. 6) these trends indicate that the CPT has deepened and moved south over the period. The MAM SLP 

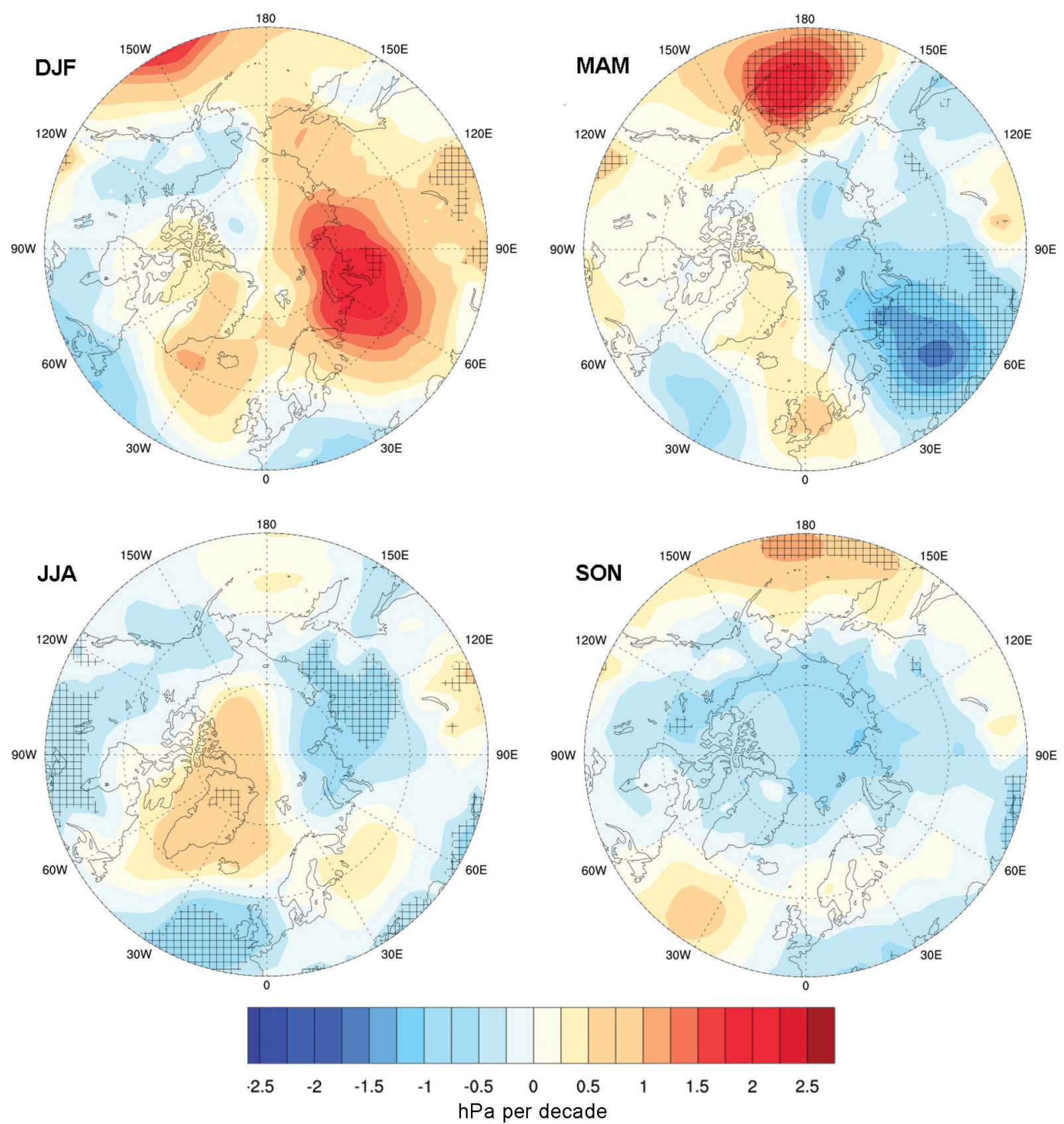

Fig. 7. High northern latitude SLP trends for the four seasons for the period 1979-2013 in the ERA-Interim reanalysis. Cross-hatching denotes regions over which the trends differ significantly from zero at the $95 \%$ confidence level.

tendencies (Fig. 8), while exhibiting considerable zonal asymmetry, do reflect aspects of the SAM spatial structure. There is a positive trend in the SAM index for this season (Fig. 9a), although its significance level is a little more modest $\left(4.94 \pm 2.55(100 a)^{-1}, p<0.10\right)$. There are no significant trends in winter or spring $(1.07 \pm 3.05$ and $-0.32 \pm 3.31(100 a)^{-1}$, respectively). In part the SIE trends can be related to the large-scale and regional anomalies displayed in Figure 8. In the austral summer the sea-ice edge is found to the south of $\sim 62^{\circ} \mathrm{S}$ at all longitudes (see, e.g., fig. 1 of Simmonds and others, 2005), and the SAM-like SLP trends indicate increasing westerly anomalies consistent with anomalous Ekman ice transport to the north. In autumn a similar process is evident, although the SAM is not as organized as in summer. By contrast, Figure $9 \mathrm{~b}$ indicates no trend in the SAM in the other two seasons, suggesting more regional influences on the SIE. In JJA a negative SLP trend is centred to the north of the ice edge between 60 and $120^{\circ} \mathrm{W}$ (Fig. 8), consistent with southward Ekman ice flux, and also an advection of ice towards the Ross Sea. Conversely, a trend to increasing westerly anomalies is evident in much of the Atlantic and Indian sectors, and an associated Ekman export of ice. Finally, in SON a cyclonic trend is evident in the Ross Sea sector just south of the ice edge, again consistent with northward Ekman export of ice (Turner and others (2009) have commented on the association between the increase in the Ross Sea sector and enhanced cyclonic flow).

\section{DISCUSSION}

We have analysed the variability and change of sea-ice extent in the two polar regions using the satellite-era data up to the most recently available (namely 1979-2013). We 

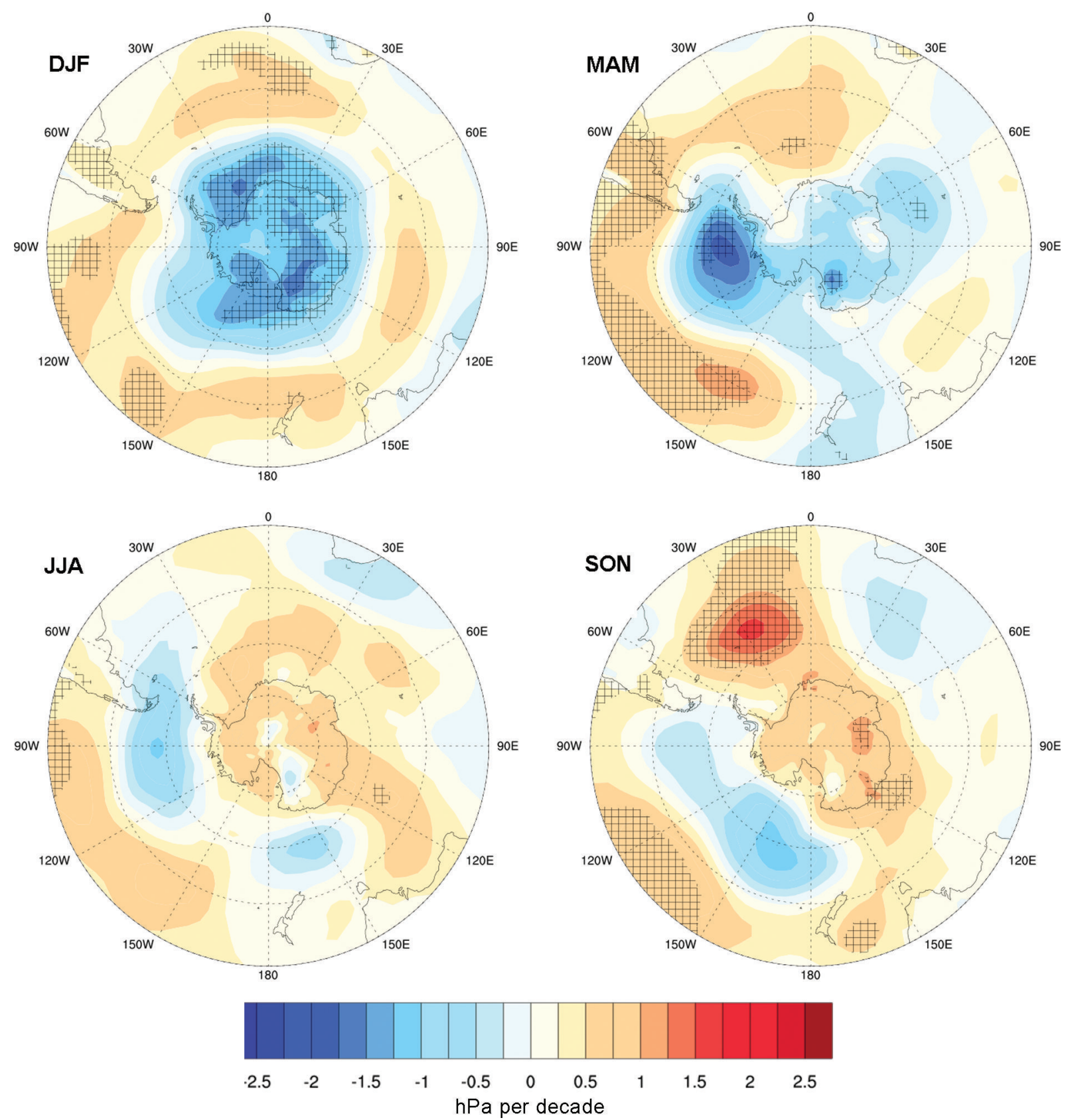

Fig. 8. Same as Figure 7, but for southern latitudes.

have stressed that sea ice exhibits a broad spectrum of temporal variability, interannual, sub-decadal and multidecadal (e.g. White and Simmonds, 2006; Bajish and others, 2013). Given this, it is important to use as long a record as possible to avoid misinterpreting signals that may be present. Our analysis has revealed that over the 35 years of record the ice loss in the Arctic has continued and there has been a significant $(p<0.001)$ decrease in SIE in all 12 calendar months, with a maximum rate of loss in September $\left((88.96 \pm 9.50) \times 10^{3} \mathrm{~km}^{2} \mathrm{a}^{-1}\right)$. This trend translates to a loss of $3 \times 10^{6} \mathrm{~km}^{2}$ over the 35 years. The annual mean rate of attrition is a dramatic $(54.58 \pm 3.70) \times 10^{3} \mathrm{~km}^{2} \mathrm{a}^{-1}$ (corresponding to a net loss of $1.86 \times 10^{6} \mathrm{~km}^{2}$ ). The contrasting positive Antarctic SIE trends achieve their maximum of $(24.27 \pm 10.59) \times 10^{3} \mathrm{~km}^{2} \mathrm{a}^{-1}$ in December, equivalent to growth of $0.83 \times 10^{6} \mathrm{~km}^{2}$ in 35 years. The increase in the $\mathrm{SH}$ annual mean, $(15.29 \pm 3.85) \times 10^{3} \mathrm{~km}^{2} \mathrm{a}^{-1}$, translates to just over $500000 \mathrm{~km}^{2}$ over the period. This rate of growth of the annual means is $\sim 28 \%$ of the rate of loss from the $\mathrm{NH}$, and hence can no longer be regarded as small.

The CMIP5 models perform quite well in the high northern latitudes, and capture the observed decrease in Arctic ice (while perhaps being too conservative as to the rate of loss) (Stroeve and others, 2012b). Similarly those models predict loss of Antarctic sea ice, a result in marked contrast to the observed increases we have documented above (Bindoff and others, 2013). This conundrum is attracting a great deal of scientific interest as to what is behind this major discrepancy. One suggestion that has been made is that the opposing $\mathrm{SH}$ trends in the models and observations might not be incompatible when seen against the background of natural (or internal) variability. Following this line, Polvani and Smith (2013) selected just four CMIP5 models, ran long integrations with 'preindustrial' forcings and concluded from the distribution of their 27 year trends that the observed trend of annual mean Antarctic 


\section{a}

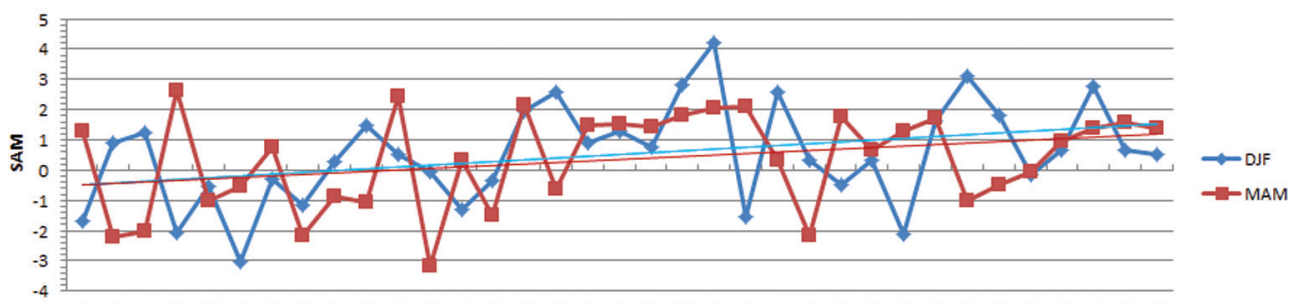

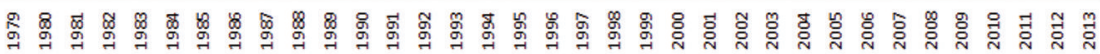

b

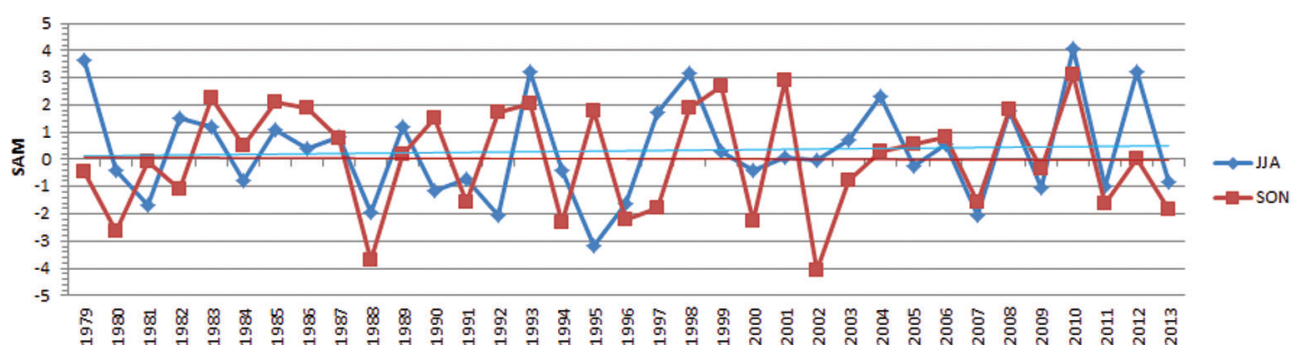

Fig. 9. Time series of the SAM index for (a) DJF and MAM and (b) JJA and SON for the period 1979-2013. The trend in DJF is significant $\left(p<0.05, r^{2}=0.13\right)$, as is that for MAM $\left(p<0.10, r^{2}=0.10\right)$. Significant trends are not detected in either JJA or SON.

SIE over 1979-2005 $\left(12.7 \times 10^{3} \mathrm{~km}^{2} \mathrm{a}^{-1}\right)$ 'lies well within the natural variability of the modeled sea ice system'. There are a number of caveats associated with this conclusion, however. Firstly, we have shown here that with recent acceleration the trend over the past 35 years has increased $\left(15.29 \times 10^{3} \mathrm{~km}^{2} \mathrm{a}^{-1}, p<0.01\right)$ while at the same time the distributions of the models' natural variability over this longer period will be more narrow. Further, Zunz and others (2013) examined a much larger sample of 24 CMIP model results and found that they greatly overestimated the variance of sea-ice extent (determined after the trends in sea-ice coverage were removed). They also showed very large differences in the abilities of the various models to capture the annual cycle of SIE, and concluded that while a critical role of the internal variability in the observed increase of sea-ice extent in the Southern Ocean could not be ruled out, 'current models results appear inadequate to test more precisely this hypothesis'. Mahlstein and others (2013) and Turner and others (2013) have made similar comments and conclude that improvements are required for the modelling of climate and climate change in the Antarctic region (see also the recent comments of Swart and Fyfe, 2012; Bengtsson and others 2013).

If natural variability is not the source of the paradox, there must be important physical processes that account for the Antarctic SIE increases over the past 35 years which are not considered or not treated correctly in climate models. There are a large number of such processes which could be relevant in the high southern latitudes. We will restrict ourselves here to mentioning one of these, namely the impact of calving or melting ice shelves. A number of investigators have documented that parts of the Antarctic ice sheet are losing ice at accelerating rates, much of which is a response to oceanic forcing, especially on the floating ice shelves (see, e.g., Hellmer, 2004, Jacobs and others, 2011; Joughin and others, 2012; Pritchard and others, 2012; Rignot and others, 2013). Basal melting of the shelves produces an influx of cool, fresh water near the surface of the ocean. A consequence of this is the stabilizing of the water column and cutting off the supply of heat from the warmer
Circumpolar Deep Water. It is argued that this, in turn, would encourage more sea-ice formation at the surface. Whether in fact this is one of the key reasons for SIE increase is yet to be established, as a number of modelling studies have arrived at varying conclusions (Stouffer and others, 2007; Bintanja and others 2013; Swart and Fyfe, 2013) and it appears that the response to Southern Ocean freshening is very sensitive to how and where the freshwater flux was added. It is clear that many more challenges await us in modelling of the high southern latitude environment.

\section{CONCLUDING REMARKS}

In this paper we have explored the variation and trends in SIE in the two polar regions using the NSIDC sea-ice dataset for the 35 year period November 1978-December 2013. This is the longest period of record used up till now, and allows us to obtain more robust estimates of change than have been obtained heretofore. We have confined our analysis to considering only the total sea-ice coverage of the Arctic and of the Antarctic. We agree with the perspectives of Lefebvre and Goosse (2008), Cavalieri and Parkinson (2012), Parkinson and Cavalieri (2012) and others that the investigation of sea-ice behaviour on a regional scale is of great importance in understanding this complex substance. However, the analysis of total coverage allows us a perspective on the net, integrated effect of regional processes and influences and is of great value in itself.

Our analysis has confirmed the ongoing loss of Arctic sea ice. We find significant $(p<0.001)$ negative trends in all months, seasons and in the annual mean. The greatest rate of decrease occurs in September, its trend of $88.96 \pm 9.50$ $\times 10^{3} \mathrm{~km}^{2} \mathrm{a}^{-1}$ representing a reduction of $3 \times 10^{6} \mathrm{~km}^{2}$ over 35 years. The analysis also confirms that the Antarctic sea-ice expansion identified in earlier studies with shorter records has continued, and our longer record allows us to determine the magnitude of these trends with greater statistical confidence than heretofore. The trends in autumn, winter, spring and for the annual mean are highly significant $(p<0.01)$, and that in summer also achieves significance 
but at a low level of $90 \%$. The positive trends in Antarctic ice can no longer be considered 'small', and the positive trend in the annual mean of $(15.29 \pm 3.85) \times 10^{3} \mathrm{~km}^{2} \mathrm{a}^{-1}$ is almost one-third of the magnitude of the $\mathrm{NH}$ annual mean decrease.

The contrasting trends in the two hemispheres raise interesting questions as to the evolution of the total amount (i.e. Arctic plus Antarctic) of sea ice over the globe. Our analysis applied to these combined data shows significant $(p<0.01)$ negative trends in three seasons (the trend in AMJ just fails to reach significance at the $90 \%$ level). The trend of the global annual mean time series, $(-35.29 \pm 5.75) \times$ $10^{3} \mathrm{~km}^{2} \mathrm{a}^{-1}$, is also highly significant.

We have commented that the Antarctic sea-ice trends simulated by the CMIP5 models have opposite signs to those revealed in our analysis of the satellite data. It has been suggested that these differences lie within the bounds of natural variability. One could argue that the longer record used here makes this suggested reason less likely. Instead, the reasons for the differences may have to be found within the physics of the models themselves. This is probably a hemisphere issue because the models perform well with respect to simulating Arctic ice and poorly for the Antarctic case.

\section{ACKNOWLEDGEMENTS}

Parts of this research were made possible by grants from the Australian Research Council and from the Australian Antarctic Science Advisory Committee.

\section{REFERENCES}

Adler RF and 12 others (2003) The Version-2 Global Precipitation Climatology Project (GPCP) monthly precipitation analysis (1979-present). J. Hydromet., 4(6), 1147-1167 (doi: 10.1175/ 1525-7541(2003)004<1147:TVGPCP >2.0.CO;2)

Bajish CC, Aoki S, Taguchi B, Komori N and Kim S-J (2013) Quasidecadal circumpolar variability of Antarctic sea ice. SOLA, 9, 32-35 (doi: 10.2151/sola.2013-008)

Bengtsson L, Hodges KI, Koumoutsaris S, Zahn M and Berrisford P (2013) The changing energy balance of the polar regions in a warmer climate. J. Climate, 26(10), 3112-3129 (doi: 10.1175/ JCLI-D-12-00233.1)

Bindoff $\mathrm{N}$ and 14 others (2013) Detection and attribution of climate change: from global to regional. In Stocker TF and 9 others eds. Climate change 2013: the physical science basis. Contributions of Working Group 1 to the Fifth Assessment Report of the Intergovernmental Panel on Climate Change. Cambridge University Press, Cambridge and New York

Bintanja R, Van Oldenborgh GJ, Drijfhout SS, Wouters B and Katsman CA (2013) Important role for ocean warming and increased ice-shelf melt in Antarctic sea-ice expansion. Nature Geosci., 6(5), 376-379 (doi: 10.1038/ngeo1767)

Blanchard-Wrigglesworth E, Armour KC and Bitz CM (2011) Persistence and inherent predictability of Arctic sea ice in a GCM ensemble and observations. J. Climate, 24(1), 231-250 (doi: 10.1175/2010JCLI3775.1)

Bracegirdle TJ and Marshall GJ (2012) The reliability of Antarctic tropospheric pressure and temperature in the latest global renanalyses. J. Climate, 25(20), 7138-7146 (doi: 10.1175/JCLID-11-00685.1)

Cavalieri DJ and Parkinson CL (2008) Antarctic sea ice variability and trends, 1979-2006. J. Geophys. Res., 113(C7), C07004 (doi: 10.1029/2007JC004564)

Cavalieri DJ and Parkinson CL (2012) Arctic sea ice variability and trends, 1979-2010. Cryosphere, 6(4), 881-889 (doi: 10.5194/tc6-881-2012)
Cavalieri DJ, Parkinson CL, Gloersen P, Comiso JC and Zwally HJ (1999) Deriving long-term time series of sea ice cover from satellite passive-microwave multisensor datasets. J. Geophys. Res., 104(C7), 15 803-15814 (doi: 10.1029/1999JC900081)

Cavalieri DJ, Parkinson CL, DiGirolamo N and Ivanoff A (2012) Intersensor calibration between F13 SSMI and F17 SSMIS for global sea ice data records. IEEE Geosci. Remote Sens. Lett., 9(2), 233-236 (doi: 10.1109/LGRS.2011.2166754)

Comiso JC (2012) Large decadal decline of the Arctic multiyear ice cover. J. Climate, 25(4), 1176-1193 (doi: 10.1175/JCLI-D-1100113.1)

Dee DP and 35 others (2011) The ERA-Interim reanalysis: configuration and performance of the data assimilation system. Q. J. R. Meteorol. Soc., 137(656), 553-597 (doi: 10.1002/qj.828)

Eisenman I, Schneider T, Battisti DS and Bitz CM (2011) Consistent changes in the sea ice seasonal cycle in response to global warming. J. Climate, 24(20), 5325-5335 (doi: 10.1175/ 2011JCLI4051.1)

Enomoto H and Ohmura A (1990) The influences of atmospheric half-yearly cycle on the sea ice extent in the Antarctic. J. Geophys. Res., 95(C6), 9497-9511 (doi: 10.1029/JC095iC06p09497)

Fetterer F, Knowles K, Meier W and Savoie M (2002) Sea ice index (updated 2013). National Snow and Ice Data Center, Boulder, CO http://nsidc.org/data/seaice_index

Hellmer HH (2004) Impact of Antarctic ice shelf basal melting on sea ice and deep ocean properties. Geophys. Res. Lett., 31(10), L10307 (doi: 10.1029/2004GL019506)

Holland PR and Kwok R (2012) Wind-driven trends in Antarctic sea-ice drift. Nature Geosci., 5(12), 872-875 (doi: 10.1038/ ngeo1627)

Jacobs SS, Jenkins A, Giulivi CF and Dutrieux P (2011) Stronger ocean circulation and increased melting under Pine Island Glacier ice shelf. Nature Geosci., 4(8), 519-523 (doi: 10.1038/ ngeo1188)

Joughin I, Alley RB and Holland DM (2012) Ice-sheet response to oceanic forcing. Science, 338(6111), 1172-1176 (doi: 10.1126/ science.1226481)

Kinnard C, Zdanowicz CM, Fisher DA, Isaksson E, De Vernal A and Thompson LG (2011) Reconstructed changes in Arctic sea ice over the past 1,450 years. Nature, 479(7374), 509-512 (doi: 10.1038/nature10581)

Lefebvre W and Goosse H (2008) An analysis of the atmospheric processes driving the large-scale winter sea ice variability in the Southern Ocean. J. Geophys. Res., 113(C2), C02004 (doi: 10.1029/2006JC004032)

Mahlstein I, Gent PR and Solomon S (2013) Historical Antarctic mean sea ice area, sea ice trends, and winds in CMIP5 simulations. J. Geophys. Res., 118(11), 5105-5110 (doi: 10.1002/jgrd.50443)

Maksym T, Stammerjohn SE, Ackley S and Massom R (2012) Antarctic sea ice - a polar opposite? Oceanography, 25(3), 140-151 (doi: 10.5670/oceanog.2012.88)

Marshall G) (2003) Trends in the southern annular mode from observations and reanalyses. J. Climate, 16(24), 4134-4143 (doi: 10.1175/1520-0442(2003)016<4134:TITSAM >2.0.CO;2)

Maslanik J, Drobot S, Fowler C, Emery W and Barry R (2007) On the Arctic climate paradox and the continuing role of atmospheric circulation in affecting sea ice conditions. Geophys. Res. Lett., 34(3), L03711 (doi: 10.1029/2006GL028269)

Ogi M and Rigor IG (2013) Trends in Arctic sea ice and the role of atmospheric circulation. Atmos. Sci. Lett., 14(2), 97-101 (doi: 10.1002/asl2.423)

Ogi $M$ and Wallace JM (2012) The role of summer surface wind anomalies in the summer Arctic sea ice extent in 2010 and 2011. Geophys. Res. Lett., 39(9), L09704 (doi: 10.1029/ 2012GL051330)

Ogi M, Yamazaki K and Wallace JM (2010) Influence of winter and summer surface wind anomalies on summer Arctic sea ice extent. Geophys. Res. Lett., 37(7), L07701 (doi: 10.1029/ 2009GL042356) 
Overland JE and Wang M (2010) Large-scale atmospheric circulation changes are associated with the recent loss of Arctic sea ice. Tellus, 62(1), 1-9 (doi: 10.1111/j.1600-0870.2009.00421.x)

Parkinson CL and Cavalieri DJ (2012) Antarctic sea ice variability and trends, 1979-2010. Cryosphere, 6(4), 871-880 (doi: 10.5194/tc-6-871-2012)

Pezza AB, Rashid HA and Simmonds I (2012) Climate links and recent extremes in Antarctic sea ice, high-latitude cyclones, Southern Annular Mode and ENSO. Climate Dyn., 38 (1-2), 57-73 (doi: 10.1007/s00382-011-1044-y)

Pistone K, Eisenman I and Ramanathan V (2014) Observational determination of albedo decrease caused by vanishing Arctic sea ice. Proc. Natl Acad. Sci. USA (PNAS), 111(9), 3322-3326 (doi: 10.1073/pnas.1318201111)

Polvani LM and Smith KL (2013) Can natural variability explain observed Antarctic sea ice trends? New modeling evidence from CMIP5. Geophys. Res. Lett., 40(12), 3195-3199 (doi: 10.1002/ grl.50578)

Polyak L and 17 others (2010) History of sea ice in the Arctic. Quat. Sci. Rev., 29(15-16), 1757-1778 (doi: 10.1016/j.quascirev. 2010.02.010)

Pritchard HD, Ligtenberg SRM, Fricker HA, Vaughan DG, Van den Broeke MR and Padman L (2012) Antarctic ice-sheet loss driven by basal melting of ice shelves. Nature, 484(7395), 502-505 (doi: 10.1038/nature10968)

Rashid HA and Simmonds I (2005) Southern Hemisphere annular mode variability and the role of optimal nonmodal growth. J. Atmos. Sci., 62(6), 1947-1961 (doi: 10.1175/ JAS3444.1)

Rignot E, Jacobs S, Mouginot J and Scheuchl B (2013) Ice shelf melting around Antarctica. Science, 341(6143), 266-270 (doi: 10.1126/science.1235798)

Screen JA and Simmonds I (2010) The central role of diminishing sea ice in recent Arctic temperature amplification. Nature, 464(7293), 1334-1337 (doi: 10.1038/nature09051)

Screen JA and Simmonds I (2012) Declining summer snowfall in the Arctic: causes, impacts and feedbacks. Climate Dyn., 38(11-12), 2243-2256 (doi: 10.1007/s00382-011-1105-2)

Screen JA, Simmonds I and Keay K (2011) Dramatic interannual changes of perennial Arctic sea ice linked to abnormal summer storm activity. J. Geophys. Res., 116(D15), D15105 (doi: 10.1029/2011JD015847)

Simmonds I (2003) Modes of atmospheric variability over the Southern Ocean. J. Geophys. Res., 108(C4), 8078 (doi: 10.1029/ 2000JC000542)

Simmonds I and Jacka TH (1995) Relationships between the interannual variability of Antarctic sea ice and the Southern Oscillation. J. Climate, 8(3), 637-647 (doi: 10.1175/15200442(1995)008<0637:RBTIVO >2.0.CO;2)

Simmonds I and Jones DA (1998) The mean structure and temporal variability of the semiannual oscillation in the southern extratropics. Int. J. Climatol., 18(5), 473-504

Simmonds I and Keay K (2009) Extraordinary September Arctic sea ice reductions and their relationships with storm behavior over 1979-2008. Geophys. Res. Lett., 36(19), L19715 (doi: 10.1029/ 2009GL039810)

Simmonds I and King JC (2004) Global and hemispheric climate variations affecting the Southern Ocean. Antarct. Sci., 16(4), 401-413 (doi: 10.1017/S0954102004002226)

Simmonds I and Rudeva I (2012) The great Arctic cyclone of August 2012. Geophys. Res. Lett., 39(23), L23709 (doi: 10.1029/ 2012GL054259)

Simmonds I, Keay K and Lim E-P (2003) Synoptic activity in the seas around Antarctica. Mon. Weather Rev., 131(2), 272-288 (doi: 10.1175/1520-0493(2003)131)

Simmonds I, Rafter A, Cowan T, Watkins AB and Keay K (2005) Large-scale vertical momentum, kinetic energy and moisture fluxes in the Antarctic sea-ice region. Bound-Layer Meteorol., 117(1), 149-177 (doi: 10.1007/s10546-004-5939-6)
Simmonds I, Burke C and Keay K (2008) Arctic climate change as manifest in cyclone behavior. J. Climate, 21(22), 5777-5796 (doi: 10.1029/2011JD015847)

Simpkins GR, Ciasto LM and England MH (2013) Observed variations in multidecadal Antarctic sea ice trends during 1979-2012. Geophys. Res. Lett., 40(14), 3643-3648 (doi: 10.1002/grl.50715)

Spielhagen RF and 8 others (2011) Enhanced modern heat transfer to the Arctic by warm Atlantic water. Science, 331(6016), 450-453 (doi: 10.1126/science.1197397)

Stouffer RJ, Seidov D and Haupt BJ (2007) Climate response to external sources of freshwater: North Atlantic versus the Southern Ocean. J. Climate, 20(3), 436-448 (doi: 10.1175/JCLI4015.1)

Stroeve JC, Serreze MC, Holland MM, Kay JE, Malanik J and Barrett AP (2012a) The Arctic's rapidly shrinking sea ice cover: a research synthesis. Climatic Change, 110(3-4), 1005-1027 (doi: 10.1007/s10584-011-0101-1)

Stroeve JC and 6 others (2012b) Trends in Arctic sea ice extent from CMIP5, CMIP3 and observations. Geophys. Res. Lett., 39(16), L16502 (doi: 10.1029/2012GL052676)

Swart NC and Fyfe JC (2012) Observed and simulated changes in the Southern Hemisphere surface westerly wind-stress. Geophys. Res. Lett., 39(16), L16711 (doi: 10.1029/2012GL052810)

Swart NC and Fyfe JC (2013) The influence of recent Antarctic ice sheet retreat on simulated sea ice area trends. Geophys. Res. Lett., 40(16), 4328-4332 (doi: 10.1002/grl.50820)

Turner J and Overland J (2009) Contrasting climate change in the two polar regions. Polar Res., 28(2), 146-164 (doi: 10.1111/ j.1751-8369.2009.00128.x)

Turner J and 8 others (2009) Non-annular atmospheric circulation change induced by stratospheric ozone depletion and its role in the recent increase of Antarctic sea ice extent. Geophys. Res. Lett., 36(8), L08502 (doi: 10.1029/2009GL037524)

Turner J, Bracegirdle TJ, Phillips T, Marshall GJ and Hosking JS (2013) An initial asessment of Antarctic sea ice extent in the CMIP5 models. J. Climate, 26(5), 1473-1484 (doi: 10.1175/ JCLI-D-12-00068.1)

Vihma T, Tisler P and Uotila P (2012) Atmospheric forcing on the drift of Arctic sea ice in 1989-2009. Geophys. Res. Lett., 39(2), L02501 (doi: 10.1029/2011GL050118)

Walsh JE (2013) Melting ice: what is happening to Arctic sea ice, and what does it mean for us? Oceanography, 26(2), 171-181 (doi: 10.5670/oceanog.2013.19)

Walsh JE and Chapman WL (2001) 20th-century sea-ice variations from observational data. Ann. Glaciol., 33, 444-448 (doi: 10.3189/172756401781818671)

Wassermann S, Schmitt C, Kottmeier C and Simmonds I (2006) Coincident vortices in Antarctic wind fields and sea ice motion. Geophys. Res. Lett., 33(15), L15810 (doi: 10.1029/ 2006GL026005)

Watkins AB and Simmonds I (2000) Current trends in Antarctic sea ice: the 1990s impact on a short climatology. J. Climate, 13(24), 4441-4451 (doi: 10.1175/1520-0442(2000)013<4441:CTIASI> 2.0.CO;2)

White WB and Simmonds I (2006) Sea surface temperature-induced cyclogenesis in the Antarctic circumpolar wave. J. Geophys. Res., 111(C8), C08011 (doi: 10.1029/2004JC002395)

Wohlleben T and 6 others (2013) Computing and representing sea ice trends: toward a community consensus. Eos, 94(40), 352 (doi: 10.1002/2013EO400006)

Zunz V, Goosse H and Massonnet F (2013) How does internal variability influence the ability of CMIP5 models to reproduce the recent trend in Southern Ocean sea ice extent? Cryosphere, 7(2), 451-468 (doi: 10.5194/tc-7-451-2013)

Zweng MM and 10 others (2013) World Ocean Atlas 2013, Volume 2: Salinity. In Levitus S ed. World Ocean Atlas 2013 (WOA13). (NOAA Atlas NESDIS 74) National Oceanographic Data Center, Silver Spring, MD http://www.nodc.noaa.gov/OC5/ woa13/pubwoa13.html 